\title{
The Role of CSR to Influence the Relationship between Institutional Ownership and Managerial Ownership on Firm Value
}

\author{
Farid Wajdi $^{{ }^{*}}$ Sekar Mayangsari $^{2}$ \\ 1. Student of the Economic Doctoral Program in Accounting Concentration, Trisakti University, Jakarta, \\ Indonesia \\ 2. Trisakti University Faculty of Economics and Business, Jakarta, Indonesia \\ *farid_wajdi@yahoo.co.id
}

\begin{abstract}
:
The goal of this study is to figure out whether institutional ownership and managerial ownership influence the company's value in moderating corporate social responsibility. The study uses data from 43 companies based on the Indonesia Stock Exchange around 2014-2018. The findings show that institutional ownership has a positive effect on firm value while managerial ownership has a negative and significant effect on firm value. Corporate social responsibility can not moderate institutional ownership on firm value. Corporate social responsibility can moderate managerial ownership of company value. As a control variables profitability and leverage have a positive and significant influence on firm value. However, company size as a control variable do not influence on firm value. The observation period is limited to only five years.
\end{abstract}

Keywords : Institutional Ownership, Managerial Ownership, Firm Value, Corporate Social Responsibility.

DOI: $10.7176 /$ RJFA/10-22-18

Publication date: November $30^{\text {th }} 2019$

\section{Introduction}

Increasing company value is the goal of the company. According to Haruman (2008), shareholders will invest their capital for companies that have high firm value because it will increase prosperity for shareholders. Ownership structure affects fluctuations in firm value. When deciding the company's value, the ownership structure is quite important. Two aspects of to consider are (1) outsider ownership concentration and (2) company ownership by management ( management ownership ). The owner of the company from an outside party is different from the manager because it is less likely that the owner of the outside party is involved in the daily business affairs of the company (Rejeki, 2007).

Agency problems are conflicts that occur between managers and shareholders (company owners). Where this tension exists in optimazing the companies value. For management, especially company executives, it is not unusual to have objectives and other priorities that clash with the main goals pf companies and often neglect the interests of investors. As shown by Jensen \& Meckling (1976), agency conflict is a disagreement that develops when the interests of managers and investors differ. The manager prioritizes personal interests because investors do not prioritize personal interest as it will decrease the companies profit and impact stock price, thereby reducing the companies value.

There is inconsistency in research on institutional ownership, such as the study of Rustan et al (2014), Muryati \& Suardikha (2014) and Lestari (2017) concluding that institutional ownership has a positive effect on firm value. But according to Warapsari \& Suaryana (2016) and Sugiarto (2011) concluded that institutional ownership has a negative effect on firm value. Research on managerial ownership also .has different results, such as Muryati \& Suardikha (2014) and Sholekah \& Venusita (2014) concluded that managerial ownership has a positive effect on firm value. However, the research results of Suastini et al (2016), Abukosim et al (2014) and Astuti (2014) show that the company's value is influenced by managerial ownership.

Corporate Social Responsibility ( CSR ) has become popular and increasingly term used between companies, governments and internal press last few years (Ditlev-Simonsen \& Wenstøp, 2011). Harvard Kennedy School issued a definition credible and complete who sees CSR as a strategy. CSR is not only related to the profits of a company but also how these benefits are generated. CSR includes more than just generosity and compliance (Patoni \& Lasmana, 2015). Other than that, CSR is also seen as a way to help companies manage impact economic, social and environmental, along with company relations with the work environment, market, supply chain, community, and domain public policy (Rahman, 2013). With thus the company is expected to be able to balance social needs and economic growth through strategic roles and competitive from company 
responsibility to the future of the company (Handajani et al, 2014). Kim et al (2012) research shows that organizations with social responsibility tends not to do earnings management through accrual discretionary or manipulate accrual operating activities. The quality of earnings can also be affected by company size. The bigger the size company, then the companies going concern will be higher in improving performance financial result company no tend to practice earnings management. Based on the above context, this study will attempt to analyze the position of CSR as a moderating factor of the institutional ownership and managerial ownership on the firm value.

\section{Literature Review Agency Theory}

The agency theory was developed by Jensen \& Meckling (1976). This theory is a grand theory of a relationship between several or even more parties, one party is being called an agent and the other being a principal. The agent is given the authority and responsibility for the decision making by the principal in accordance with the mutually agreed work contract Agrawal \& Knoeber (1996) propose an important role for institutional investors as external stock market supervisors. Agrawal and Mandelker also suggest that institutional investors provide valuable supervisory services and act as a barrier to the opportunistic behavior of company managers.

\section{Legitimacy Theory}

The action of an entity that is desired, appropriate, or appropiate in several systems of norms, values, beliefs, and definitions that are socially constructed is an understanding of legitimacy (Suchman, 1995). According to Haniffa \& Cooke (2005), in The legitimacy theory to get legitimacy from society, companies must have a commitment to the community to carry out activities based on the values of justice. Therefore, the company understands that a determinant in the company's survival is the interaction between the company and the environmental community in which it exists.

\section{Managerial Ownership}

Decision-making for the amount owed, and also net income from own capital based on share ownership held by top management is a definition of institutional ownership (Aluy et al, 2017). Comparison between management ownership and institutional ownership can be used in problem-solving in the company (Jensen \& Meckling, 1976).

\section{Institutional Ownership}

According Bushee (2005), large shareholders and institutional experience stress to the manager to focus on use long-term values than short-term addition, Brockman \& Michayluk (1998) find an information processing hypothesis that is consistent with the pattern of observation institutional trade, namely institutional investment, will look at the process of creating information relating to the company.

\section{Firm Value}

According to da Silveira \& Barros (2011), shareholders are evaluating the concept of firm value as what is shown in the stock price on the capital market. According to Nuraina (2012) awards are given for share prices that are above book value per share, while depreciation arises when the share price is below the book value per share. Confidence is the performance of the company will increase when the stock market prices are high and make the company value high, not only in the present but also in the future (Hermuningsih, 2013).

\section{Corporate Social Responsibility (CSR)}

The accounting literature includes many interpretations of corporate social responsibility, but Carroll (1979) interpretation is not unquestionable or widely accepted. According to Carrol (1979,p.289), socially responsible corporations have to work in four different areas, such as finance, morality, law, and compassion. Kim et al., (2012) conclude that organizations with higher CSR scores tend to use discretionary accruals to manage profits; however, CSR firms seem to be more likely to retain continuity with their financial reports and provide highquality income. Gras-Gil et al (2016) claim that income-reducing accruals and income-increasing accruals will be used by managers to achieve income goals, therefore the magnitude of actual discretionary accruals is used to determine the level of income control, so that the magnitude of actual discretionary accruals is used to evaluate the quality of earnings. 


\section{a. Hypothesis development}

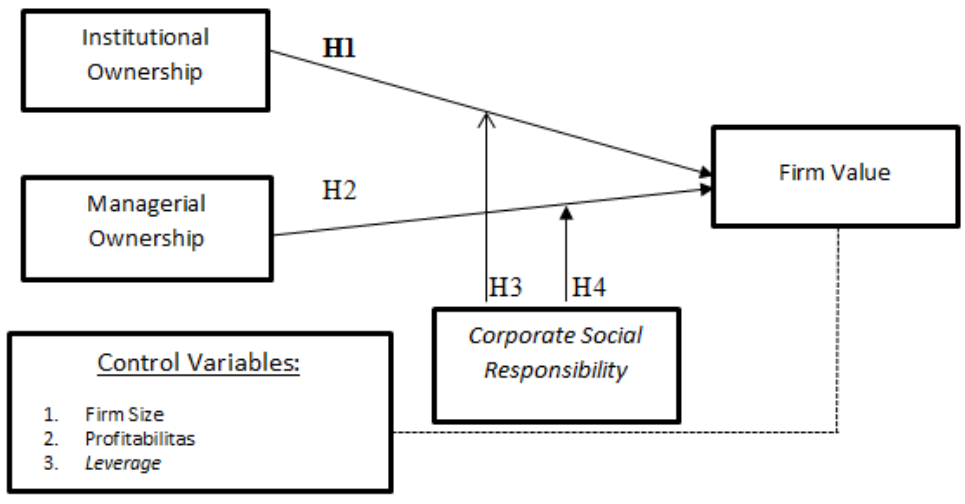

Figure 1 : Research Concept

\section{The Effect of Institutional Ownership on Firm Value}

Agency theory explains the gap between principals and agents because of differences in interests. These differences in interests make the agency costs borne by the company. To reduce agency conflicts that occur, it can be done by increasing institutional ownership. Rustan et al., (2014) found that institutional ownership has a positive effect on firm value. Muryati \& Suardikha (2014) found that institutional ownership has a significant positive effect on firm value. The research. conducted by Lestari (2017) also found that institutional ownership has a positive effect on firm value. This shows the owner's control role is key to improving the companies performance. Research results from Warapsari \& Suaryana (2016) and Nasser (2008), however, found that institutional ownership had a negative effect on firm value. This shows that institutional ownership is dominated by parties that are not independent (affiliated with each other) so that the function of institutional ownership as a supervisor for management cannot run properly even though the ownership of shares by institutional parties is high. This condition causes agency problems cannot be suppressed and can impact on the company's declining market value. In this research the following hypothesis is established on the basis of the description:

H1 : Institutional ownership has a positive effect on firm value

\section{The Effect of Managerial Ownership on Firm Value}

Agency theory by Jensen \& Meckling (1976) states that one way of reducing the expense of the agency is to maximize ownership of companies by management. Managerial ownership ownership must suit management and shareholders' interest. As a concequence of a wrong decision, management will suffer directly from the decision taken and bear the losses. Muryati \& Suardikha (2014), as well as Sholekah \& Venusita (2014), found that managerial ownership significant positive effect on firm value. However, results of the study by Suastini et al., (2016) and Nasser (2008) show that managerial ownership has a negative and significant effect on firm value. Although managerial ownership has risen, but due to managerial ownership in manufacturing companies from 2010-2013 the company's value does not rise at less than a hundred percent, i.e. it has an average of 5.09 percent descriptively so that managerial ownership is not replied by shareholders as a positive signal in increasing corporate quality. In this research the following hypothesis is established on the basis of the description:

H2 : Managerial ownership has a positive effect on firm value.

\section{The Effect of Institutional Ownership on Firm Value moderated Corporate Social Responsibility}

Kusumadilaga (2010), Servaes \& Tamayo (2013) and Munawaroh (2014) have shown that the scale of CSR activities affects the increase in value of the company. Oktavia (2014) showed that the proportion of institutional ownership held by foreign firms had a positive influence on social responsibility disclosure. This is because foreign parties want to know the company's concern for the community for the activities carried out by the company so that foreign parties can know about environmental, and social issues based on the company's 
operations. This research, however, is not consistent with Anissa \& Machdar (2014) which show that institutional ownership has a negative influence on corporate social responsibility disclosure. It indicates that institutional ownership is more concentrated on corporate profits only to allow the company to conduct and schedule reports of corporate social responsibility. Because of the existence of contradictions in this study of independent variables (institutional ownership, managerial ownership) on firm value, CSR is used in this analysis as a moderating variable to assess whether the relationship between variable CSR and independent variables (managerial ownership, institutional ownership) can reinforce or weaken the dependent variable (firm value). In this research the following hypothesis is established on the basis of the description:

H3 : Institutional ownership has a positive effect on firm value moderated corporate social responsibility (CSR)

\section{The Effect of Managerial Ownership on Firm Value moderated Corporate Social Responsibility}

Corporate social responsibility contributes to financial performance of the company. As shown by Brine et al (2007) if the company wants to increase long-term finance which will increase the company's value, the company must consider various social and environmental problems that arise. Research conducted by Anissa \& Machdar (2014) shows managerial ownership has a positive effect on corporate social responsibility disclosure. The higher level of managerial ownership, the higher disclosure of corporate social responsibility. This shows that companies which have management as shareholders will think about the welfare of shareholders so that management will act more objectively through the disclosure of social responsibility. The result is also in line with Uwuigbe (2011), Fauzyyah \& Rachmawati (2018) show that managerial ownership has a negative effect on corporate social responsibility. Because of the existence of contradictions in this study of independent variables (institutional ownership, managerial ownership) on firm value, CSR is used in this analysis as a moderating variable to assess whether the relationship between variable CSR and independent variables (managerial ownership, institutional ownership) can reinforce or weaken the dependent variable (firm value). In this research the following hypothesis is established on the basis of the description:

H4 : Managerial ownership has a positive effect on firm value moderated corporate social responsibility (CSR)

\section{Methodology}

\subsection{Sample Selection}

The company listed for the year 2014-2018 on the Indonesian Stock Exchange is the analytical unit or object to be investigated in this case. Sample selection by means of a method of purpose sampling to achieve a random sample based on the criteria defined. The criteria for samples: (1) Listed Companies during 20142018. (2) Publish a complete annual report for 2014-2018. (3) To have complete data on the variables used in the analysis, for example, to report ownership and institutional ownerhip data.

\subsection{Variables and measurements}

\section{a. Dependent Variable}

Tobin's $Q$ is being used to calculate the value of the company.

b. Independent Variables

$$
\text { Tobin's Q }=\frac{\text { (Mve }+ \text { Dser }}{\text { Total Assets }}
$$

1) Institutional ownership (IO) is proxied by institutional shareholders such as Limited Liability Companies with a percentage of the issuer's companies shares. The formula used by Bathala et al (1994) to assess institutional ownerhip is:

$$
\text { Institutional Ownership }=\begin{gathered}
\text { number of institution ally sharas } \\
\text { number of shares watsundirg }
\end{gathered}
$$

2) Managerial ownership (MO) proxied by the Board of Commission ownership (BOC) and the Board of Directors (BOD). The equation used to determine the institutional ownership of Bagnani et al (1994) is as follows:

$$
\text { Managerial Ownership }=\frac{\text { number of managerial shares }}{\text { mumher of ahnora witstundisg }}
$$

c. Moderating variable in this research is Corporate Social Responsibility (CSR), determined by the amount of disclosure divided by the maximum amount of disclosure. The formula used to assess corporate social responsibility according to Haniffa \& Cooke (2005) is as follows:

$$
\mathrm{CRSD}_{\mathrm{j}}=\frac{2 \mathrm{xij}}{\mathrm{n}}
$$


$\mathrm{CRSD}_{\mathrm{j}}$ : Corporate Social Responsibility Indeks j

$\mathrm{N} \quad$ : Number of items for the company, $\mathrm{n} \leq 32$

$\mathrm{X}_{\mathrm{ij}} \quad$ : Dummy variable, 1 if the object is included in the disclosure and 0 if it is not disclosed.

d. Control Variables

The control variables in this research are:

1) Company size. The equation used to determine company size according to Taliyang et al (2011) is:

Company size $=$ Ln Total Aktiva

2) Profitability. The equation used to determine profitability according to Hoyt \& Liebenberg (2011) is:

$$
\text { ROA }=\frac{\text { Net tucone }}{\text { Dow Value of Aaset }}
$$

3) Leverage. The equation used to determine leverage according to Li et al (2014) is:

$$
\mathrm{DER}=\frac{\text { Bask value of zinbility }}{\text { Dook value of Equity }}
$$

\section{Result and Discussion}

This research takes a sample from the 2014-2018 Indonesia Stock Exchange on non-financial companies. The company also publishes annual financial reports. Data on managerial ownership, institutional ownership and reporting on social responsibility are specific criteria. Based on purposive sampling technique, a sample of 43 companies consisting of various business groups was obtained.

\section{a. Normality Test}

The probability value is $0,092>0,05$ based on test results, suggesting that the residual data are normally distributed. It means the normality expectations have been met by the panel data regression model.

\section{b. Multicollinearity Test}

Multicollinearity test is carried out by evaluating the correlation function in the regression model between independent variables, the regression model is considered not to contain multicollinearity if there is no coefficient value between independent variables exceeding 0,9. Table 1 the results pf the research show there is no correlation coefficient between independent variables exceeding 0,9 , so it can be assumed that multiocollinearity does not exist in the model.

\section{Table 1 Multicollinearity test results}

\begin{tabular}{|c|c|c|c|c|c|c|c|c|c|}
\hline Variabel & TOBINS_Q & OK & OM & CSR & MOD_OI & MOD_OM & ROA & SIZE & DER \\
\hline TOBINS_Q & 1.000 & & & & & & & & \\
\hline OI & -0.499 & 1.000 & & & & & & & \\
\hline OM & 0.157 & -0.793 & 1.000 & & & & & & \\
\hline CSR & 0.135 & 0.067 & -0.050 & 1.000 & & & & & \\
\hline MOD_OI & -0.383 & 0.335 & -0.223 & -0.899 & 1.000 & & & & \\
\hline MOD_OM & 0.162 & -0.715 & 0.899 & 0.109 & -0.281 & 1.000 & & & \\
\hline ROA & 0.366 & 0.100 & -0.006 & 0.004 & 0.056 & 0.057 & 1.000 & & \\
\hline SIZE & 0.158 & 0.096 & -0.072 & 0.549 & -0.492 & -0.035 & 0.192 & 1.000 & \\
\hline DER & -0.082 & -0.264 & 0.338 & -0.301 & 0.137 & 0.077 & -0.295 & -0.165 & 1.000 \\
\hline
\end{tabular}

\section{c. Heteroscedasticity Test}

Based on table 2 the outcoe of heteroscedasticity test, Obs * R Squared is 0,1745 , as the probability value obatined is $>0,05$, so it can be assumed that heteroscedasticity does not exist in the model. 
Table 2 Heteroscedasticity test results

Heteroskedasticity Test: Glejser

\begin{tabular}{llll}
\hline \hline F-statistic & 1.461511 & Prob F $(8,160)$ & 0.1753 \\
Obs*R-squared & 11.50876 & Prob Chi-Square (8) & 0.1745 \\
Scaled explained SS & 9.362218 & Prob Chi-Square (8) & 0.3127 \\
\hline \hline
\end{tabular}

\section{d. Autocorrelation Test}

Based on table 3 autocorrelation test results, the resulting probability value is 0,2637 , because the observed probability value is $>0,05$, it is inferred that the regression model does not have autocorrelation.

\section{Table 3 Autocorrelation test results}

Breusch-Godfrey Serial Correlation LM test :

\begin{tabular}{llll}
\hline \hline F-statistic & 1.266167 & Prob F (2,158) & 0.2848 \\
Obs*R-squared & 2.665908 & Prob Chi-Square (2) & 0.2637 \\
\hline \hline
\end{tabular}

\section{e. Regression Analysis}

Multiple linear regression analysis results include t-test results. F test results, and determination coefficient estimation results. The consequence of linear regression analysis with the aid of EVIEWS version 9 is the effect of independent variables on firm value.

Table 4 Regression analysis results

Dependent Variable : TOBINS_Q

Method : Least Squares

Date : 06/27/19 Time 05:59

Sample : 1169

Included observations : 169

\begin{tabular}{crlrl}
\hline \hline Variable & Coefficient & Std.Error & t-Statistic & Prob. \\
\hline \hline OI & 6.784768 & 1.731817 & 3.917715 & 0.0001 \\
OM & -12.41315 & 1.361897 & -9.114598 & 0.0000 \\
CSR & -13.93694 & 1.825074 & -7.636370 & 0.0000 \\
MOD_OI & -14.47492 & 1.803798 & -8.024690 & 0.0000 \\
MOD_OM & 22.41463 & 3.417447 & 6.558881 & 0.0000 \\
ROA & 3.607550 & 0.341563 & 10.56188 & 0.0000 \\
SIZE & 0.011060 & 0.017752 & 0.622998 & 0.5342 \\
DER & 0.037537 & 0.013449 & 2.791100 & 0.0059 \\
C & 8.085252 & 0.618367 & 13.07517 & 0.0000 \\
\hline \hline R-squared & 0.759028 & Mean dependent variable & 1.308902 \\
Adjusted R-squared & 0.746979 & S D dependent variable & 0.630213 \\
S.E of regression & 0.317005 & Akaike info criterion & 0.591984 \\
Sum squared resid & 16.07872 & Schwarz criterion & 0.758665 \\
Log likelihood & -41.02266 & Hannan-Quinn criteria & 0.659626 \\
F-statistic & 62.99703 & Durbin-Watson stat & 1.793026 \\
Prob (F-statistic) & 0.000000 & & & \\
\hline \hline
\end{tabular}




\section{The Effect of Institutional Ownership on Firm Value}

The probability values of the effect of institutional ownership variable (OI) on firm value (Tobin's Q) is 0,001 due to the results of the regression analysis, with a regression coefficient marked as positive. Because the obtained probability value is $<0,05$ and the regression coefficient is positive, Ho is rejected and it assumed that institutional ownership has a positive and significant effect on firm value. The company's higher institutional ownership the higher the value of the company. In line with Rustan et al, (2014) found that institutional ownership has a positive effect on firm value. The same study from Muryati \& Suardikha (2014) found that institutional ownership had a significant positive effect on firm value. Agency cost will decrease and the firm value will rise if the rate of institutional ownership increase, the level of control of outside party control will increase.

\section{The Effect of Managerial Ownership on Firm Value}

The probability values of the effect of managerial ownership variable $(\mathrm{OM})$ on firm value (Tobin's $\mathrm{Q})$ is 0,000 due to the results of the regression analysis, with a regression coefficient marked as positive. Because the obtained probability value is $<0,05$ and the regression coefficient is negative, Ho is rejected and it assumed that managerial ownership has a negative and significant effect on firm value. The company's higher managerial ownership, the lower the companies value. The result of this study is not consistent with Muryati \& Suardikha (2014) found that managerial ownership has a significant positive effect on firm value.

The study results are consistent with Lee \& Ryu (2003) opinion that the ownership structure is a potential negative that can effect the value of the company. The existence of information asymmetry between company management and outsiders allows high transaction costs for outsiders. It is believed that the management's entry as the holder of the companies shares reduces risk of outsiders as management often bears the burden of the value of the company. The study results are also consistent with the results of Haruman (2008), which shows that the variable of managerial ownership influence the company's value with the direction of negative relations. The decline in the company's value was due to opportunistic actions taken by managerial shareholders. Managerial ownership wants high income compared to the growth of investment in the company, so that if managerial ownership is high then the market tends to react negatively which causes the companies value to decrease.

\section{The Effect of Instutional Ownership on Firm Value moderated Corporate Social Responsibility}

The probability value of CSR's moderating effect on the firm value of institutional ownership (OI) is 0,000 . Because the probability value obtained is $<0,05$, Ho is denied and it is concluded that the influence of institutional ownership on firm value can be moderated by CSR.

Social inequality and environmental damage due to company operational activities can be carried out through corporate social responsibility. Companies that carry out CSR activities regularly will certainly make a positive impression on the company in the long run. Besides getting public support and recognition, investors will be interested in investing their capital so as to improve the performance of shares on the stock exchange. This is in accordance with the research of Kusumadilaga (2010), Servaes \& Tamayo (2013) and Munawaroh (2014) showing that the size of CSR practices influences the increase on firm value. Because of the existence of inconsistencies in the study of independent variables (institutional ownership, managerial ownership) on corporate value, in this study CSR is used as a moderating variable to determine whether the interaction between CSR variables and independent variables (managerial ownership, institutional ownership) can strengthen or weaken the dependent variable (firm value).

\section{The Effect of Managerial Ownership on Firm Value moderated Corporate Social Responsibility}

The probability value of CSR's moderating effect on the firm value of managerial ownership (OM) is 0,000 . Because the probability value obtained is $<0,05$, Ho is denied and it is concluded that the influence of managerial ownership on firm value can be moderated by CSR.

Corporate social responsibility contributes to financial performance of the company. As shown by Brine et al (2007) if the company wants to increase long-term finance which will increase the company's value, the company must consider various social and environmental problems that arise. Because of the existence of. inconsistencies .in the study of independent variables, (institutional ownership, managerial ownership) on firm value, in this study CSR is used as a moderating variable to determine whether the interaction between CSR 
variables and independent variables (managerial ownership, institutional ownership) can strengthen or weaken the dependent variable (firm value).

Profitability as a control variable calculated by Return on Assets effect on firm value because the significant value is 0,000 smaller that the coefficient value $(0,05)$. Profitability is the profit-generating potential of the organization (Hanafi \& Halim, 2016). High-profit companies should increase the companies value as profitability shows good company prospects in order to drive demand for stocks. The result of this study consistent with Devi et al (2017) and Bertinetti et al (2013) which show that profitability influences firm value.

Leverage as a control variable calculated by Debt to Equity ratio has a significant value of 0,0059 smallet than the coefficient value $(0,05)$. This show that this variable effect on firm value. Li et al, (2014), Khumairoh (2016) found that leverage affects firm value. It indicates that the higher the use of debt, the higher the value of the company.

Size of the company as a control variable calculated by total assets has a significant value of $0,5342>0,05$. This shows that this variable has no effect on firm value. The results of this study consistent Arifah \& Wirajaya (2018) which show that firm size does not affect firm value. Large companies do not always have stable conditions so they cannot drive company value.

\section{Conclusions}

The results of this study can be conclude namely, (1) Institutional ownership has a positive effect on firm value. This result shows, that the higher institutional ownership, the higher the value of the value of the company and vice versa. (2) Managerial ownership has a negative effect on firm value. This This result shows, that the higher institutional ownership, the lower the value of the value of the company and vice versa. (3) CSR has a negative effect on firm value. This result show that companies that are to high to do CSR will reduce the value of the company. (4) CSRR can strengthen the influence of institutional ownership on firm value. (5) CSRR can strengthen the influence of managerial ownership on firm value.

The limtations of this research as follows, (1) The observation period is limited to five years of observation. (2) In deciding the disclosure index, there is an element of subjectivity because there is no guideline that can be used as a reference standard for calculating corporate social responsibility disclosure so that the calculation of the index for indicators in the same class that vary between each researcher.

Future research can be done by using another kind of samples such as the finance industry or by using new variables such as Enterprise Risk Management, Public Ownership, Independent Commissioner, and Audit Committee.

\section{REFERENCE}

Abukosim, Mukhtaruddin, Ferina, I. S., \& Nurcahaya, C. (2014). Ownership Structure And Firm Values: Empirical Study On Indonesia Manufacturing Listed Companies. Journal of Arts, Science \& Commerce.

Agrawal, A., \& Knoeber, C. R. (1996). Firm Performance and Mechanisms to Control Agency Problems between Managers and Shareholders. The Journal of Financial and Quantitative Analysis. https://doi.org/10.2307/2331397

Aluy, C. A., Tulung, J. E., \& Tasik, H. H. (2017). Pengaruh Keberadaan Wanita dalam Manajemen Puncak dan Kepemilikan Manajerial Terhadap Kinerja Keuangan Perbankan (Studi Pada Bank BUMN dan Bank Swasta Nasional Devisa di Indonesia). Jurnal EMBA: Jurnal Riset Ekonomi, Manajemen, Bisnis Dan Akuntansi.

Anissa, D., \& Machdar, M. (2014). Pengaruh Kepemilikan Manajerial, Kepemilikan Institusional, Dan Kepemilikan Asing Terhadap Pengungkapan Tanggung Jawab Sosial Perusahaan. Widya Warta, 9-18.

Arifah, E., \& Wirajaya, I. G. A. (2018). Pengaruh Pengungkapan Enterprise Risk Management Terhadap Nilai Perusahaan Dengan Ukuran Perusahaan, Leverage, dan Profitabilitas Sebagai Variabel Kontrol. E-Jurnal Akuntansi. https://doi.org/10.24843/eja.2018.v25.i02.p30

Astuti, L. (2014). Analisis Pengaruh Profitabilitas, Kebijakan Deviden, Kebijakan Hutang dan Kepemilikan Manajerial terhadap Nilai Perusahaan. Naskah Publikasi Universitas Muhammadiyah Surakarta. 
BAGNANI, E. S., MILONAS, N. T., SAUNDERS, A., \& TRAVLOS, N. G. (1994). Managers, Owners, and The Pricing of Risky Debt: An Empirical Analysis. The Journal of Finance. https://doi.org/10.1111/j.15406261.1994.tb05148.x

Bathala, T., Moon, P., \& Rao, R. P. (1994). Policy, Ownership , Managerial Impact of Institutional Holdings : An Perspective. Financial Management.

Bertinetti, G. S., Cavezzali, E., \& Gardenal, G. (2013). The Effect of the Enterprise Risk Management Implementation on the Firm Value of European Companies. SSRN Electronic Journal, (August). https://doi.org/10.2139/ssrn.2326195

Brine, M., Brown, R., \& Hackett, G. (2007). Corporate social responsibility and financial performance in the Australian Context. Australian Accounting, Business and Finance Journal. https://doi.org/10.1002/hrm

Brockman, P., \& Michayluk, D. (1998). Individual versus institutional investors and the weekend effect. Journal of Economics and Finance, 22(1), 71-85. https://doi.org/10.1007/BF02823234

Bushee, B. J. (2005). Institutional Investors, Long-term Investment, And Earnings Management. SSRN Electronic Journal. https://doi.org/10.2139/ssrn.52686

Carroll, A. B. (1979). A Three-Dimensional Conceptual Model of Corporate Performance. Academy of Management Review, 4(4), 497-505. https://doi.org/10.5465/amr.1979.4498296

da Silveira, A. D. M., \& Barros, L. A. B. de C. (2011). Corporate Governance Quality and Firm Value in Brazil. SSRN Electronic Journal. https://doi.org/10.2139/ssrn.923310

Devi, S., Budiasih, I. G. N., \& Badera, I. D. N. (2017). Pengaruh Pengungkapan Enterprise Risk Management Dan Pengungkapan Intellectual Capital Terhadap Nilai Perusahaan. Jurnal Akuntansi Dan Keuangan Indonesia, 14(1), 20-45. https://doi.org/10.21002/jaki.2017.02

Ditlev-Simonsen, C. D., \& Wenstøp, S. (2011). Companies ${ }^{e e}$ Ethical Commitment -An Analysis Of The Rhetoric In CSR Reports. Issues In Social And Environmental Accounting, 5(1), 65. https://doi.org/10.22164/isea.v5i1.55

Fauzyyah, R., \& Rachmawati, S. (2018). the Effect of Number of Meetings of the Board of Commissioners, Independent Commissioners, Audit Committee and Ownership Structure Upon the Extent of Csr Disclosure. The Accounting Journal of Binaniaga, 3(02), 41. https://doi.org/10.33062/ajb.v3i2.232

Gras-Gil, E., Palacios Manzano, M., \& Hernández Fernández, J. (2016). Investigating the relationship between corporate social responsibility and earnings management: Evidence from Spain. BRQ Business Research Quarterly. https://doi.org/10.1016/j.brq.2016.02.002

Hanafi, M. M., \& Halim, A. (2016). Analisis Laporan Keuangan (Edisi Keli). Yogyakarta: UPP STIM YKPN.

Handajani, L., B, S., Sutrisno, \& Saraswati, E. (2014). Pengungkapan Tanggung Jawab Sosial Perusahaan: Determinan dan Konsekuensi. Simposium Nasional Akuntansi XVII Mataram, 1-34.

Haniffa, R. M., \& Cooke, T. E. (2005). The impact of culture and governance on corporate social reporting. Journal of Accounting and Public Policy. https://doi.org/10.1016/j.jaccpubpol.2005.06.001

Haruman, T. (2008). Pengaruh Struktur Kepemilikan Terhadap Keputusan Keuangan dan Nilai Perusahaan. Simposium Nasional Akuntansi XI Pontianak.

Hermuningsih, S. (2013). Profitability, Growth Opportunity, Capital. Bulletin of Monetary, Economics and Banking,.

Hoyt, R. E., \& Liebenberg, A. P. (2011). The Value of Enterprise Risk Management. Journal of Risk and Insurance, 78(4), 795-822. https://doi.org/10.1111/j.1539-6975.2011.01413.x

Jensen, M., \& Meckling, W. (1976). Theory of the firm: Managerial behaviour, agency costs and ownership. Strategic Management Journal.

Khumairoh. (2016). PENGARUH LEVERAGE, PROFITABILITAS, DAN UKURAN PERUSAHAAN TERHADAP NILAI PERUSAHAAN (Studi Empiris pada Perusahaan Garment dan Textile yang terdaftar di Bursa Efek Indonesia Tahun 2011-2015). Syariah Paper Accounting, (2011), 71-81.

Kim, Y., Park, M. S., \& Wier, B. (2012). Is earnings quality associated with corporate social responsibility? Accounting Review. https://doi.org/10.2308/accr-10209 
Kusumadilaga, R. generated by shopping centres in A. ( A. (2010). Pengaruh Corporate Social Responsibility Terhadap Nilai Perusahaan Dengan Profitabilitas Sebagai Variabel Moderating (Studi Empiris pada Perusahaan Manufaktur yang Terdaftar di Bursa Efek Indonesia). Skripsi Fakultas Ekonomi.

Lee, S.-M., \& Ryu, K. (2003). Management Ownership and Firm's Value: An Empirical Analysis Using Panel Data. SSRN Electronic Journal, (593). https://doi.org/10.2139/ssrn.444420

Lestari. (2017). Pengaruh Kepemilikan Institusional dan Struktur Modal TerhadapNilai Perusahaan. Jurnal Riset Manajemen Dan Bisnis (JRMB), 2(1), 293-306.

Li, Q., Wu, Y., Ojiako, U., Marshall, A., \& Chipulu, M. (2014). Enterprise risk management and firm value within China's insurance industry. Acta Commercii. https://doi.org/10.4102/ac.v14i1.198

Munawaroh, A. (2014). Pengaruh Profitabilitas Terhadap Nilai Perusahaan dengan Corporate Social Responsibility Sebagai Variabel Moderating. Jurnal Ilmu Dan Riset Akuntansi.

Muryati, N., \& Suardikha, I. (2014). Pengaruh Corporate Governance Pada Nilai Perusahaan. E-Jurnal Akuntansi, 9(2), 425-429.

Nasser, E. M. (2008). Pengaruh Stuktur Kepemilikan Dan Dewan Komisaris Independen Terhadap Nilai Perusahaan Dengan Manajemen Laba Dan Kebijakan Hutang Sebagai Variabel Intervening. Media Riset Akuntansi, Auditing Dan Informasi, Vol. 8, p. 1. https://doi.org/10.25105/mraai.v8i1.740

Nuraina, E. (2012). Pengaruh Kepemilikan Institusional Dan Ukuran Perusahaan Terhadap Kebijakan Hutang Dan Nilai Perusahaan (Studi Pada Perusahaan Manufaktur Yang Terdaftar Di Bei). AKRUAL: Jurnal Akuntansi. https://doi.org/10.26740/jaj.v4n1.p51-70

Oktavia, D. N. D. N. (2014). Hubungan Struktur Kepemilikan Pada Pengungkapan Tanggungjawab Sosial Perusahaan Publik Indonesia. Jurnal Ekonomi Dan Bisnis Universitas Diponegoro Semarang, 03, 1-16.

Patoni, A., \& Lasmana, A. (2015). Pengaruh Harga Saham dan Frekuensi Perdagangan Saham terhadap Bid-Ask Spread (Studi Empiris pada Perusahaan Manufaktur yang Melakukan Stock Split di Bursa Efek Indonesia Selama Periode 2009-2014). Jurnal Akunida.

Rejeki, Sr. (2007). Analisis Pengaruh Struktur Kepemilikan, Ukuran Perusahaan dan Rasio Perputaran Persediaan terhadap Pemilihan Metode Persediaan pada Perusahaan Manufaktur Go Public di BEJ. Skripsi Tidak Dipublikasi, Fakultas Ekonomi, Universitas Semarang.

Rustan, Said, D., \& Rura, Y. (2014). Pengaruh Struktur Kepemilikan terhadap Nilai Perusahaan: Kualitas Laba dan Kebijakan Hutang sebagai Variabel Intervening. Jurnal Analisis.

Servaes, H., \& Tamayo, A. (2013). The impact of corporate social responsibility on firm value: The role of customer awareness. Management Science. https://doi.org/10.1287/mnsc.1120.1630

Sholekah, F. W., \& Venusita, L. (2014). Pengaruh Kepemilikan Manajerial, Kepemilikan Institusional, Leverage, Firm Size, dan Corporate Social Responsibility terhadap Nilai Perusahaan Pada Perusahaan High Profile yang Terdaftar di Bursa Efek Indonesia Periode 2008-2012. Jurnal Ilmu Manajemen.

Suastini, N. M., Purbawangsa, I. B. A., \& Rahyuda, H. (2016). Pengaruh Kepemilikan Manajerial Dan Pertumbuhan Perusahaan Terhadap Nilai Perusahaan Pada Perusahaan Manufaktur Di Bursa Efek Indonesia. EJurnal Ekonomi Dan Bisnis Universitas Udayana.

Suchman, M. (1995). Managing Legitimacy : Strategic and Institutional Approaches . Academy of Management. Academy of Management Review, 20(3), 571-611. https://doi.org/10.2307/258788

Sugiarto, M. (2011). Pengaruh Struktur Kepemilikan dan Kebijakan Dividen terhadap Nilai Perusahaan dengan Kebijakan Hutang Sebagai Intervening. Jurnal Akuntansi Kontemporer, 3(1), 1-25.

Taliyang, S. M., Sultan, U., Abidin, Z., Latif, R. A., \& Mustafa, N. H. (2011). The determinants of intellectual capital disclosure among malaysian listed companies. International Journal of Management and Marketing Research, 4(3), 25-33.

Uwuigbe, U. (2011). An Examination of the Relationship between Management Ownership and Corporate Social Responsibility Disclosure: A Study of Selected Firms in Nigeria. Research Journal of Finance and Accounting, 2(6), 23-30.

Warapsari, A. A. A. U., \& Suaryana, I. G. N. A. (2016). E-Jurnal Akuntansi Universitas Udayana SEBAGAI VARIABEL INTERVENING Fakultas Ekonomi dan Bisnis Universitas Udayana ( Unud), Bali , Indonesia 
email: ayuucca@yahoo.com Fakultas Ekonomi dan Bisnis Universitas Udayana ( Unud), Bali , Indonesia ABSTRAK Nil. 16, 2288-2315. 